\title{
Biblical Myths and Humanism in Cat's Cradle and Slaughterhouse-Five
}

\author{
R. Joseph Ponniah \\ Department of English, Mepco Engineering College, Sivakasi, Tamil Nadu, India \\ E-mail:joseph_pnnh@yahoo.com
}

KEYWORDS Harmless Untruth. Man-centered Religion. Apocalyptic Vision

\begin{abstract}
This paper examines how Vonnegut uses biblical myths and his newly created religion Bokononism as effective weapons to uphold the worth of human beings in the contemporary society. He searches for a new way of life through this religion to make human existence meaningful amid the incomprehensible realities of the present day scientific world. He has incorporated the philosophy of humanism in this religion. It searches for morality through human means in support of human interests. The paper also analyzes how Vonnegut's theories and concepts of religion would help man to survive in the world devoid of values.
\end{abstract}

Vonnegut employs biblical myths to render his vision effectively. He recommends the myths that console human beings and criticizes the myths that consider rituals and religious systems primary. He feels that myths of a religion must comfort and console people and they should not threaten them. Since biblical stories are very popular, Vonnegut uses biblical myths to present his ideas sharply and effectively to his readers. He borrows the Edenic myth from the Bible to analyze the purpose of man and to pursue the state of innocence. He also recommends unconditional love through his newly created religion Bokononism as recommended by Christ in the New Testament.

Vonnegut's novels Cat's Cradle and Slaughterhouse-Five are apocalyptic especially in respect to religion. He expects birth of a new man after apocalypse. He discusses the end of the world in both novels. In spite of his apocalyptic vision, he believes in the beginning of a new world. He foresees a better society in the future. He exposes the fragmented nature of modern life. He is actually yearning for a sense of order in an otherwise chaotic world around. Slaughterhouse - Five takes readers away to another planet where things are in harmony. It is Vonnegut's quest for an ideal order.

Vonnegut, in his newly created religion in Cat's Cradle, implies that man should renew his connection with the modern scientific world to overcome new difficulties. He believes in a new set of values that help to understand the society. When the Government in San Larenzo fails to make life smooth, Bokononism becomes an instrument of hope. It provides people with better and better lies, both because truth is the enemy of people, and because it is terrible. Bokononists induce people to forget truth because all the religions are based on harmless untruth.

Bokononism advocates faith in an international brotherhood. It ignores national, institutional, occupational and class boundaries. It cultivates the quality of acceptance. It fulfils God's will without discovering what people are doing because any investigation into the nature of work will result in failure. Whatever man does or whatever happens to him is an inevitable fate. He lives as long as his fate permits him to live. According to Bokononism, man should not feel scared about death. He has no free will. God decides his life. The religion thus gives people of San Larenzo a new mythology, a new set of lies or harmless untruth.

In the Book of Bokonon, the prophet reveals that people should live by 'foma' or harmless untruths that make them brave, kind, healthy and happy. Bokononists believe that there is no such thing as absolute evil or absolute good and to understand the nature of goodness, it is necessary to know about evil. It is easy to distinguish good from evil only when man has thorough knowledge about both. The struggle between good and evil becomes meaningful for Bokononists.

If natives of San Larenzo understand the concept of good and evil then a lie helps them understand truth. Bokononists believe that man must create foma, the lies that make him laugh aloud at the cosmic absurdity with which he is 
faced. "The 'lies' of this particular religion", says Klinkowiz, "are purgative, restoring man's happiness, balance, and comfort. Bokononism reorders the notion of the finite world. So that we may accept it, rather than simply rebel against it in fruitless anger" (Klinkowiz 1982). The doctrine of the religion helps to dismiss horrors resulting from wars between nations. It has been described as a "religion after alienation because it carefully removes evil from the self" (Scatt 1976). It is a religion that sees evil and good as co-existing in a world filled with paradoxes. It reacts against horrors created by modern science. It realizes that God does not intervene in human affairs.

Bokononism is against conventional religions that give importance to rituals. It is a mancentered religion. It considers man as primary. John, the protagonist of the novel, begins his journey as a Christian trying to write a book 'The Day the World Ended' and ends his journey as a Bokononist because he is interested in creating a man-centered religion. However, the doctrine of the religion resembles the doctrine of Christianity in many ways. Comforting lies are actually the same in Bokononism and in Christianity. Priests in Christianity tell people harmless untruths in pulpits while giving ceremony. Harmless untruths are necessary for churches because they help people accept their misfortunes.

The biblical apocalyptic vision is also echoed in this novel. In the book 'The Day the World Ended', John gives a factual account of the day the atom bomb or scientific truth was dropped on Hiroshima. Kurt Vonnegut commands this "scientific truth" as:

I used to be an optimist during my boyhood in Indianapolis....My brother Bernard... Made me very

Enthusiastic about science for a while. I thought

Scientists were going to find out exactly

Everything worked, and then makes it work

Better...Scientific truth was going to make us so

Happy and comfortable.... What actually happened when

I was twenty-one was that we dropped

Scientific Truth on Hiroshima. We killed everybody

There (Clark 1977).

Here, Vonnegut is worried about the destructive capabilities of knowledge. He also links knowledge to the fall of Adam and Eve in
Genesis "where the acquisition of the knowledge of good and evil came at the expense of the native innocence, dignity and immortality" (Mustazza 1990).

John, in the course of his research, inquires into the life of Dr Felix Hoenikker, the so-called father of atom bomb, who is responsible for the 'End of the World'. John, then, begins to question about the ice-nine, a device for freezing water that Felix Hoenikker playfully invents at the suggestion of an army general. When the icenine slips into the sea, the whole seawater freezes into ice. It is an echo of the book of Revelation, leaving us with the image of the void earth where "there was no longer any sea" (Nelson 1984). Boknonon, the prophet tries to reinvent the universe by inventing the religion Bokononism to survive the onslaught of war. After the destruction caused by the scientific technology, he emerges with a new set of values on the new earth as "the first earth had passed away" (Nelson 1984).

Bokonon preaches the gospel of the religion to the people in San Larenzo "to save them from suicidal despair through the power of saving lies (myth in the colloquial sense)" (Mustazza 1990). $\mathrm{He}$ writes the doctrine of their religion in Calypsis:

I wanted all things

To seem to make some sense,

So we all could be happy, yes

Instead of tense,

And I made up lies

So that they all fit nice

A pa-ra-dise (Vonnegut 1965).

Bokonon revises the book of Genesis by making man encounter God when He creates man out of mud and gives life to him:

In the beginning God created the earth, and He looked upon it in His cosmic loneliness.

And God said, "Let us make living creatures out of mud, so the mud can see in what we have done". And God created every living creature that moveth, and one was man. Mud as a man alone could speak. God leaned close as mud as man sat up, looked around, and spoke. Man blinked. "What is the purpose of all this?" he asked politely.

Everything must have a purpose? Asked God.

"Certainly", said man.

"Then I leave it to you to think of one for all this," said God. And He went away (Vonnegut 1965). 
God does not tell man the specific purpose of His creation but He asks man to find it because he is attributed with the knowledge to think. Therefore, man uses his knowledge to explore outer space to find a purpose. This prevents him from loving people and he does not understand that the real purpose in this universe is to love humanity. He fails to use his knowledge for helping humanity and instead he pursues knowledge for his fame.

Dr Felix Hoenikker, in Cat's Cradle, invents atom bomb and ice-nine for his fame and name. This is because he treats science as a game, and his discoveries as happy incidents. When a fellow scientist remarks after the Hiroshima incident that science has now known sin; he replies, 'What is sin?' Through the portrayal of Hoenikker, Vonnegut shows his concern that science is removed from the context of humanism. Despite its danger, science continues to be unquestionably accepted, even worshipped in Cat's Cradle as 'magic that works'. Vonnegut uses the Edenic myth to elucidate our proud pursuit of knowledge and to explain our destructive tendencies. "Eden is this planet. If that is so, then we are still in it. It may be that we are poisoned by all our knowledge, are still crawling toward the gate" (Vonnegut 1981). Man can prevent himself from moving away from God, if knowledge is used for understanding one's fellow beings and if it is not used for annihilating mankind. "Why don't we use it to devise realistic methods for preventing us from crawling out of the gate of the Garden of Eden? We're such wonderful mechanics, may be can we lock that gate with us inside" (Vonnegut 1981).

Vonnegut, in Slaughterhouse-Five, explicitly links the experience of his characters to the Edenic myth. Even though they are pushed forward unmercifully by time and circumstances, they move backward to the world of Adam and Eve to pursue the state of innocence. Billy and his companions are taken as prisoners of war by a group of German soldiers. One of the German corporals wears golden cavalry boots of a dead Hungarian colonel. A recruit watches the boots of the colonel and says, "If you look in there deeply enough, you'll see Adam and Eve" (Vonnegut 1969). Billy suddenly stares into the corporal's boot and "saw Adam and Eve in golden depths. They were naked. They were so innocent, so vulnerable, so eager to behave decently" (Vonnegut 1969). Billy is able to see the beauty of Eve in the face of the innocent young corporal. In order to have Edenic innocence, Vonnegut takes his characters to the Garden of Eden. Vonnegut feels that man has lost his peace of mind because of his mad pursuit of knowledge. Adam and Eve have lost their peace and the Edenic life because of the pursuit of knowledge. Vonnegut takes myths from the Bible to find meaning for man's life. Myths help him a lot to give a doctrine of life to man. He uses myths to preach people to love one another. He yearns for Edenic innocence in his novels. He ascribes values to human being. Yearning for the past recurrently occurs in his novels.

The mythical significance of the novel emerges in an analysis of the events of Billy's affirmative years. Billy has experienced the cruel tyranny of the God of this universe and has learned to hate life in his universe in the figure of his own father. The meaninglessness of the gruesome crucifixion is obvious through the life of Christ. Christ's father subjects him to a terrible death. Billy's father uses the cruel sink or swim method to teach Billy how to survive in the life giving water. This is a grotesque rite of baptism. Vonnegut identifies the water as the Y.M.C.A. (Young Men's 'Christian' Association) pool. Billy prays to God to get him out of the Cavern and in lieu he is plunged into total darkness that makes him doubt his existence. The only 'ghostly' light that points to him is the radium light of his father's watch. In order to get rid of such fears in the world, Billy travels to the other planet, Tralfamadore.

Billy's description of his own death includes several gospel parallels. When a crowd of people protest Billy's announcement of his death, he rebukes them. He says them that death is not a terrible thing. If people think that death is terrible, then they have not understood the concept of eternal present. Billy rebukes the crowd like Jesus Christ: "Do you not yet perceive or understand? Are your hearts hardened? Having eyes do you not see, and having ears do you not hear. And do you not remember.... Do you not yet understand?" (Nelson 1984). Billy says that it is time for them to go home to their wives and children and it is time for him to die for a little while and then to live again. After experiencing death for a while, he resurrects.

Slaughterhouse-Five is narrated in the form of the Judeo-Christian Bible. In the Bible, time proceeds from the creation to man's fall and the 
crucifixion to resurrection. Vonnegut also tries in Slaughterhouse-Five to do what the gospel writers have attempted to do. He revised the New Testament in the novel on a book by Kilgore Trout called The Gospel From the Outer Space. Trout feels that the traditional Gospels are flawed because they suggest people to learn the moral lesson from the crucifixion of Jesus Christ. Trout does not justify the crucifixion of Christ. He says, "before you kill somebody, make absolutely sure he isn't well connected" (Vonnegut 1969). In Trout's revised version of the story, Jesus is nobody rather then being the Son of God. "The heaven opens up with thunder and lighting when this nobody is crucified, and God announces that he will punish horribly anybody who torments a bum who has no connections" (Vonnegut 1969). It becomes clear in the course of the novel that the clownishly dressed Billy is precisely this 'bum who had no connections'. Like Jesus, Billy accepts his death at the hands of his enemies. Both of them teach mankind that one must face death calmly, for death is not the end. In the Christian vision, the self after death proceeds forward in time eternally either to hell or to heaven. According to Tralfamadore or Billy's vision, the self after death proceeds backward in time or into life. Billy, a bum who has no connection with sin, is in a way a new Christ who becomes a victim of war. But at the same time, it is difficult to accept him to be a Christ figure because he saves no life. He is not valiant enough to face the hard realities of these systems. He is weak, fragile and sensitive. Billy escapes to an imaginary Eden-Tralfamadore to overcome his problems. He discovers a different way to the life governed by a different set of values. His travel to Tralfamadore and the knowledge he brings back reveal his desire to escape from the duties of the world in which he is living. On the contrary, Christ preaches to share with people.

Vonnegut's Bokononism and his views on religion in Cat's Cradle and Slaughterhouse-Five serve as an antidote against the dangers created by science. He feels that new systems are essential for man to live happily in this universe. He tries to find meaning in this absurd universe by creating new religions based on human values in his novels. If man follows the existing system, he will go to pieces. Therefore, Vonnegut uses his religions to guide people to live happily in this universe and to mock the absurdity of the present day scientific world.

\section{REFERENCES}

Clark Mayo Kurt 1977. Vonnegut: The Gospel From Outer Space. California: Borgo Press.

Kilinkowitz Jerome 1982 Kurt Vonnegut. New York: Methen.

Mustazza Leonard 1990. Forever Pursuing Genesis: The Myth of Eden in the Novels of Kurt Vonnegut. Lewisburg: Bucknell University Press.

Nelson Thomas 1984. The Holy Bible: New King James Version. Nashville: Thomas Nelson Publishers.

Scatt Stanley 1976. Kurt Vonnegut, Jr. Boston: Twayne Publishers.

Vonnegut Kurt 1965. Cat's Cradle. London and Tonbridge: The White Friars Press Ltd.,

Vonnegut Kurt 1969. Slaughterhouse-Five: The Children's Crusade. New York: Dell Publishing Co. Inc.

Vonnegut Kurt 1981. Palm Sunday: An Autobiographical Collage. New York: Delacorte. 